УДК 355.34:94

CIPA O. Ю.

http://orcid.org/0000-0001-8689-2641

https://doi.org/10.33577/2313-5603.33.2020.175-193

\title{
ЦЕНТР МАЙСТЕРНОСТІ СПЕЦАЛЬНИХ ОПЕРАЦЙ АРМІЇ США: ІСТОРИЧНИЙ ДОСВІД У ФОРМУВАННІ КАДРОВОГО ПОТЕНЦІАЛУ СПЕЦПІДРОЗДІЛІВ
}

У статті коротко розкрито історію створення, розвитку та функціонування Центру майстерності спеціальних операцій армії США (U.S. Army's Special Operations Center of Excellence) (далі - SOCoE). Проаналізовано концепцію формування кадрового потенціалу спецпідрозділів і структуру Центру. Відзначається, що навчальний заклад $\epsilon$ не тільки школою підготовки досвідчених фахівців спецпідрозділів, а й сучасним аналітичним центром, динамічною інноваційною структурою, що розвивається й удосконалюється відповідно до викликів військовополітичної обстановки сьогодення. Висвітлено роль $\mathrm{SOCoE}$ як механізму, який дозволяє створити передумови для успішного вирішення спільних завдань, покладених на підрозділи Сил спеціальних операцій федеральних відомств Сполучених Штатів і силових структур іноземних держав та України.

Ключові слова: Сили спеціальних операцій США, військові навчальні заклади, Центр майстерності спеціальних операцій армії США, SOCoE, Центр і школа спеціальних бойових дій імені Джона Ф. Кеннеді, USAJFKSWCS, Командування спеціальних операцій США, USASOC.

Постановка проблеми у загальному вигляді. Світові соціальноекономічні та суспільно-політичні зміни у другій половині XX на початку XXI століть разом 3 науково-технічним прогресом, що їх супроводжував, призвели до суттєвих змін у середовищі безпеки, у тому числі й принципах ведення війни. Зросла роль нетрадиційних способів досягнення тактичних і стратегічних цілей. Широкомасштабне застосування танків, авіації та ракет в цих умовах малоефективне, проте зросла роль партизанських і різних політичних, економічних, фінансових, інформаційних та психологічних підривних операцій. Виконання таких завдань покладається на підрозділи спеціального призначення, котрі у провідних країнах блоку НАТО та в Україні, реформуються у самостійний компонент - Сили спеціальних операцій (ССО).

Зростання вагомості спецоперацій у війнах четвертого покоління, до яких належать «гібридні війни», вимагає всебічного вивчення теоретичних засад і на їх основі формування кадрового

Сіра Оксана Юріївна, курсовий офіцер навчального курсу Інституту морально-психологічного забезпечення Національної академії сухопутних військ імені гетьмані Петра Сагайдачного, м. Львів

(C) Cipa O.Ю., 2020 
потенціалу Сил спеціальних операцій. Безперечним лідером 3 цього погляду є США. Сполучені Штати стали першою державою, яка 3 кінця 1980-х років перетворила війська та інші структури спеціального призначення у самостійний компонент збройних сил і створила мережу науково-дослідних і освітніх центрів. Цей важливий науковий і практичний досвід, теоретичні засади організації освітнього процесу потребують всебічного вивчення, аналізу і впровадження у вітчизняну систему підготовки фахівців спецпідрозділів, що є особливо актуальним в умовах війни, розв'язаної Російською Федерацією на Сході України.

Теоретичний та практичний інтерес складає саме функціонування таких структур в арміях іноземних держав, їх особливості, відмінності та спільні риси з українською системою підготовки. Досвід США певною мірою близький Україні, оскільки обидві країни змушені протистояти діяльності добре підготовлених, всебічно забезпечених й технічно оснащених терористичних угруповань, організацій і держав. Слід зазначити, що після набуття чинності 21 лютого 2019 року змін до Конституції, які закріпили курс України на членство в СС і НАТО, та початку переходу Збройних сил України на ј-структури військового управління, набуває особливого значення дослідження історичного досвіду творення і розвитку військової освіти країн Північноатлантичного альянсу. Актуальність дослідження обумовлена також реалізацію в Збройних силах України проєкту «Розвиток системи військової освіти та підготовки військових фахівців» що передбачає створення системи військової освіти, яка забезпечить навчання та підготовку офіцерського й сержантського складу з метою набуття здобувачами нових освітніх і професійних компетентностей, операційної сумісності на основі стандартів, ухвалених у збройних силах держав - членів НАТО (3а два роки очікуються реформи військової освіти, 2019).

Проблематика удосконалення освітнього процесу є пріоритетною для передових ВВНЗ України, де щорічно відбуваються робочі зустрічі щодо реалізації заходів у рамках програми «Удосконалення військової освіти» (DEEP - Defence Education Enhancement Program) за участю представників Консорціуму оборонних академій та дослідницьких інституцій програми НАТО, координаторів заходів Програми DEEP 3 боку американської сторони, представників збройних сил Данії, Канади, ФРН та інших 
експертів з питань військової освіти (Національну академію сухопутних військ відвідали експерти НАТО, 2019).

Аналіз останніх досліджень і публікацій, в яких започатковано розв'язання цієї проблеми і на які спирається автор, виділення невирішених раніше частин загальної проблеми присвячується стаття. Проблематика військ спеціального призначення провідних країн в різні часи порушувалась у працях вітчизняних і зарубіжних дослідників. У радянській історіографії, яку розвивали фахівці закритих науково-дослідних центрів спецслужб або відповідних вищих закладів освіти, готувалися науково-навчальні та інформаційно-аналітичні праці щодо історії творення, організації й тактики застосування спецпідрозділів армій Північноатлантичного альянсу і деяких інших держав - ймовірних противників СРСР. Згадані роботи зберегли інформаційно-пізнавальне значення і донині.

Пострадянський період також відзначився виходом праць науково-популярного характеру або перекладів закордонних видань стосовно військ спеціального призначення. В останні роки в інформаційно-аналітичних виданнях провідних країн НАТО, Міністерства оборони Російській Федерації, Республіки Білорусь 3'явилася низка праць енциклопедичного й довідкового характеру з історії військ спеціального призначення, які, утім, висвітлювали структуру, шлях елітних військ певних країн, участь їх у відомих військових кампаніях (Мартьянов О., 2010, Метров О., 2014). В умовах реформування Збройних сил України, вдосконалення системи підготовки на основі стандартів держав - членів НАТО, особливого значення набувають праці таких вітчизняних авторів, як А. Слюсаренко, Д. Вєдєнєєв, Г. Биструхін, А. Семука, С. Александров, О. Анікєєнко, І. Данилюк, О. Печорін, С. Тітенко та багато інших. Автори проводили теоретичне узагальнення історичного досвіду творення та бойового застосування Сил спеціальних операцій як явища військової історії, детально аналізували побудову національних моделей ССО, організаційних структур, підготовки та застосування спецпідрозділів в антитерористичних операціях. Проте теоретичне узагальнення військовоісторичного характеру саме системи підготовки кадрового потенціалу ССО окремих країн проведено в меншому обсязі: поза увагою дослідників залишаються новації й перспективи розвитку, функціонування та реформування структури навчальних закладів, 
алгоритму підготовки та комплектування офіцерського і сержантського корпусу, взаємного інтегрування підготовки спецпідрозділів і загальновійськової освіти.

Формулювання мети статті (визначення завдання). Метою статті $\epsilon$ дослідження сутності та конкретних проявів процесу творення, реформування й розвитку системи підготовки кадрового потенціалу спецпідрозділів армії США в контексті трансформації Сил спеціальних операцій Збройних Сил України яка покликана максимально наблизити їх структуру до стандартів Північноатлантичного альянсу.

Виклад основного матеріалу дослідження з обгрунтуванням отриманих наукових результатів. У Міністерстві оборони Сполучених Штатів створена розвинена мережа науково-дослідних i освітніх центрів. Вона дозволяє організовувати навчальний процес, здійснювати перепідготовку військовослужбовців, проводити наукові дослідження, розвивати інноваційну діяльність у сфері забезпечення національної безпеки (Слюсаренко, 2019: 171).

Особливе місце в системі військової освіти займає Центр і школа спеціальних бойових дій імені Джона Ф. Кеннеді (U.S. Army John F. Kennedy Special Warfare Center and School USAJFKSWCS), який розташований у Форт-Брегг, штат Північна Кароліна. Сьогодні навчальний заклад має ще одну назву - Центр майстерності спеціальних операцій армії CША (U.S. Army’s Special Operations Center of Excellence - SOCoE). Діяльність закладу розпочинається після закінчення Другої світової війни. Історичні події того часу: промова Й. Сталіна на зборах виборців (1946), фултонська промова В. Черчілля (1946) та проголошення «доктрини Трумена» стали точками відліку «холодної війни». Чітко визначене глобальне протистояння двох наддержав, боротьба за зони впливу, вимагала від сторін залучення до конфліктів i втручання в розвиток подій у будь-якій частині світу. Саме 3 цього часу починається цільова підготовка фахівців спец підрозділів армії США. У 1947 році у Форт-Райлі (штат Канзас) був сформований Оперативний підрозділ психологічної війни - «загін тактичної інформації» Сухопутних військ США, який восени 1950 р. був перетворений на «1-шу роту звукомовлення та видання листівок». Рота брала участь у корейській війні як підрозділ тактичної пропаганди 8-ї американської армії. У 1950-1951рp. Міністерство армії у Форт-Райлі утворило Управління психологічної 
війни (Psychological Warfare Division - PSYWAR) та розгорнуло підготовку спеціальних кадрів у загальновійськовій школі Сухопутних військ (Еволюиія структур інформаційно-психологічного протиборства сил спецьоперацій армії, 2019).

У квітні 1952 року Управління перейменовано у Центр психологічних операцій (Psychological warfare Center), а навчальна база була перенесена до Форт-Брегг, штат Північна Кароліна (Academic Handbook FY 2019, 2019). 20 червня 1952 року на базі спецпідрозділів Центрального розвідувального управління США була створена 10-та група спеціального призначення (10th Special Forces Group). Цю дату вважають часом створення військ спеціального призначення США. Для підготовки військовослужбовців використовували найдосконаліші методики того часу. Усі новобранці прийшли 3 повітрянодесантних або «рейнджерських» підрозділів. Майбутніх «зелених беретів» вчили перебувати на території противника протягом декількох місяців, іноді без підтримки ззовні. Для цього особливу увагу приділяли вивченню мов і звичаїв країни ймовірних бойових дій. Під час підготовки США активно співпрацювали з Великою Британією - фахівцями Спеціальної повітряної служби (Special Air Service - SAS).

Викладачами стали колишні офіцери Управління стратегічних служб США та офіцери, що мали бойовий досвід. Новобранців спочатку готували індивідуально за окремими спеціальностями: оперативна діяльність і розвідка, зброя, диверсійна діяльність, зв'язок, медична допомога. Особливу увагу приділяли мистецтву партизанської війни: безпеці, проведенню диверсій, розвідувальній діяльності, методам втечі 3 полону й ухилення від бою. Курсанти освоювали нові спеціальності й відпрацьовували злагодженість дій у складі групи. Групові навчання проходили на території Національного лісового парку Чатагучі (штат Джорджія). 3 тих часів одним зі стандартних методів Сил спеціального призначення США стало залучення до навчань місцевого цивільного населення, поліції та частин Національної гвардії. Підрозділи групи спеціального призначення поперемінно діяли як партизани. Далі курсанти засвоювали способи десантування з моря та освоювали методи ведення бойових дій у суворих умовах гірського клімату. Після завершення підготовки на початку 1953 р. 10-та група спеціального призначення була відправлена у Корею, де 
бійці діяли в ролі військових радників 3 питань ведення партизанської війни (Вєдєнєєв, 2010: 95).

У 1956 році Центр психологічних операцій був перейменований у Школу спеціальних бойових дій (Special Warfare School SWS). На Школу було покладено відповідальність за розробку доктрини, способів ведення операцій, організація підготовки та навчання персоналу спеціальних сил та психологічних операцій (Academic Handbook FY 2019, 2019). 31960 року Школа запровадила вивчення новітніх форм і способів ведення контрпартизанської боротьби.

Великий вклад у розвиток навчального закладу зробив 35-й Президент США Джон Ф. Кеннеді, який уділяв багато уваги розвитку спецпідрозділів армії США. Це особливе відношення було закріплено 12 жовтня 1961 року, коли президент відвідав Форт-Брегг для огляду військ у Школі спеціальних бойових дій. Саме після історичної зустрічі між Кеннеді і майбутнім бригадним генералом Вільямом Ярборо Джон Ф. Кеннеді своїм Указом затвердив знаковий «зелений берет» (USAJFKSWCS dedicates Kennedy-Yarborough statue. Special Warfare, 2012). За рішенням президента берети такого кольору стали офіційним елементом уніформи й відмітним знаком Сил спеціальних операцій армії США (Коммандос: Формирование, подготовка, выдающиеся операции спецподразделений, 1999). Під впливом Президента підрозділи «зелених беретів» стали справжньою культурною елітою серед збройних сил США - спецпризначенці зобов'язані були не просто розбиратися в тактиці диверсій і розвідки, а й знати іноземні мови та культурні особливості країн, в яких їм належало діяти. У 1961 році він наказав збільшити штат спецпідрозділів (за час президентства Кеннеді їх число зросло до двох 3 половиною тисяч) і готувати їх відповідно до концепції партизанських i антипартизанських воєн. Своє бачення цієї концепції Кеннеді виклав у виступі перед випускниками Військової академії Вест-Пойнт у червні 1962 року. За його словами, сучасні війни стають війнами диверсій і засідок, інфільтрацій і партизанських дій: «Це ще один вид війни, новий за своєю інтенсивністю, давній за своїм походженням - війна 3 партизанами, підривниками, повстанцями, вбивцями, війна із засідки замість бою; шляхом проникнення, а не агресії, пошуку перемоги, 
розмиваючи та виснажуючи ворога, замість того, щоб залучати його» (United States Military Academy Commencement Address, 1962).

У 1962 році у складі Школи спеціальних бойових дій була заснована нова група підготовки спеціальних сил для відбору кандидатів 3 добровольців, що залучаються до виконання оперативних завдань (Слюсаренко, 2019: 178), також сформований відділ для вивчення та розробки складних методів інфільтрації та ексфільтрації (infiltration and exfiltration) - тактичним діям, заснованим на процесі проникнення на ворожу територію та швидкого виведення військових і цивільних осіб з місця ведення бойових дій або з ворожого середовища в безпечне місце.

16 травня 1969 року Школу було перейменовано в Центр військової допомоги імені Джона Ф. Кеннеді. Навчальну програму було розширено задля забезпечення тренування спеціалістів зі стрибків з парашутом на великих та малих висотах та підводним операціям. Центр складався зі Школи Спеціальних сил, Школи Психологічних операції та військових радників й навчальної бригади (Academic Handbook FY 2019, 2019).

1 квітня 1972 року з Форт-Гордона, штат Джорджія, у ФортБрегг було переведено Школу цивільних справ Армії США, яка увійшла до штату Центру.

У 1973 році Центр був підпорядкований створеному Командуванню навчання та доктрин СВ США (United States Army Training and Doctrine Command - TRADOC), якому на теперішній час підпорядковані 37 шкіл і центрів. 1 червня 1982 року начальник штабу армії затвердив рішення про відокремлення Центру для самостійної діяльності у складі TRADOC під новою назвою Центр спеціальних бойових дій імені Джона Ф. Кеннеді (U.S. Army John F. Kennedy Special Warfare Center - SWC). Центр інтегрував методи спеціальних бойових дій в армійські системи навчання та операції, ставши основною школою для Сил спеціальних операцій армії США.

У 1985 році SWC отримав сучасну назву Центр і школа спеціальних бойових дій імені Джона Ф. Кеннеді (U.S. Army John F. Kennedy Special Warfare Center and School - USAJFKSWCS). В цей час були створені перші шість навчальних відділів: спеціальних сил; спеціальних способів ведення бойових дій; виживання, ухилення, опору та відступу; спеціалістів із закордонних 
територій; цивільних справ; психологічних операцій. Через кілька років була також заснована Академія підготовки сержантів.

20 червня 1990 року USAJFKSWCS був перепідпорядкований 3 TRADOC Командуванню спеціальних операцій армії США (U.S. Army Special Operations Command - USASOC). Це надало Командуванню повний контроль над усіма компонентами Сил спеціальних операцій США (United States special operations forces - SOF), за винятком підрозділів передового базування. Протягом 1990-х років і у XXI столітті основною місією USAJFKSWCS було поповнення військ висококваліфікованими фахівцями спецоперацій. У 2011 році після оптимізації були додані три додаткових навчальних батальйони, і 2 грудня 2012 року USAJFKSWCS отримав нову назву - Центр майстерності спеціальних операцій армії США (U.S. Army's Special Operations Center of Excellence - SOCoE) (Academic Handbook FY 2019, 2019).

Сьогодні навчальний заклад проводить оцінювання, відбір, навчання бійців і командирів спецпідрозділів питанням цивільної справи, психологічним операціям, а також розроблює доктрину та створює можливості для повного забезпечення всього спектру військових операцій та конфліктів. Головна мета i бачення підготовки - завдяки інноваційному навчанню і вихованню забезпечити країну високоосвіченою, інноваційною та адаптивною силою; формування експертів спеціальних бойових дій на рівні, що дозволяє пристосуватися і досягти успіху в складному, багатовимірному світі (Academic Handbook FY 2017, 2017).

В інтересах підготовки курсантів й слухачів Центр здійснює взаємодію 3 іншими навчальними закладами ССО ЗС США, Центрального розвідувального управління, а також 3 федеральними структурами й різними органами державної влади Сполучених Штатів (Турыгин, 2018: 41). SOCoE також тісно співпрацює $з$ рекрутинговим батальйоном спеціальних операцій (Special Operations Recruiting Battalion - SORB), який відповідає за вербування солдатів 3 армії в полки цивільних справ, психологічних операцій та спеціального призначення.

До складу Центру майстерності спеціальних операцій армії США входять Управління й Центр і школа спеціальних бойових дій імені Джона Ф. Кеннеді. 
В Управлінні налічується п'ять осіб, у тому числі: начальник центру (категорія генерал-майор), його заступник (бригадний генерал), начальник штабу (полковник), головний ворент-офіцер (старший ворент-офіцер п'ятого класу) та головний сержант (сержант-майор).

Заступнику начальника Центру підпорядковане Управління забезпечення якості освіти (Quality Assurance Office - QAO), що відіграє ключову роль у розвитку, моніторингу та звітуванні про якість підготовки фахівців у навчальному закладі. Штаб організує роботу служб і взаємодію зі структурами штабу армії в системі органів військового управління країн-членів НАТО: G-1 (управління кадрів), G-2 (управління розвідки), G-3 (оперативне управління), G-4 (логістика), G-6 (зв'язок), G-8 (бюджетне управління і фінанси, управління ресурсами).

Центр спеціальних бойових дій (Special Warfare Center) підпорядкований Командуванню спеціальних операцій США (USASOC). Він розробляє теоретичні положення спеціальних операцій, програми навчання, кадрову політику та програми розвитку фахівцівлідерів Сил спеціальних операцій США і інтегрує їх в Командування спеціальних операцій армії США (ARSOF).

До складу Центру спеціальних бойових дій входить:

- головне управління Центру (Directorate Management Office DMO) (начальник - категорія полковник);

- управління розробки програм навчання і доктрини бойових дій (Directorate of Training and Doctrine - DOTD);

- відділ цивільних справ (Civil Affairs Commandant - CA) (начальник - категорія полковник);

- відділ психологічних операцій (SOF Psychological Operations Commandant - PO) (начальник - категорія полковник);

- відділ Сил спеціального призначення (Special Forces Commandant - SF) (начальник - категорія полковник);

- центр інтеграції досвіду армійських спеціальних операцій (Army Special Operations Capabilities Integration Center - ARSOCIC);

- відділ навчання, освіти та розвитку лідерів Сил спеціальних операцій армії (ARSOF Training, Leader Development, and Education - TLDE);

- центр кадрової політики та програм ARSOF (ARSOF Personnel Policies and Programs Center);

- відділ медіа виробництва (Media Production Division - MPD). 
Управління розробки програм навчання і доктрини бойових дій (DOTD) є основним координаційним центром. Це гібридна організація, що утворена після оптимізації Центру у 2011 році. Основні напрями роботи: розробка доктрини, підбір кадрів, інтеграція системи навчання фахівців $\mathrm{CCO} 3$ професійною загальновійськовою освітою; узагальнення досвіду спеціальних бойових дій; інтеграція армійського досвіду у теоретичні положення для використання у навчанні; підготовка навчальних програм для формування лідерських якостей; управління навчанням; забезпечення підтримки інноваційних технологій навчання; медіа виробництво (Academic Handbook FY 2016, 2016).

Головними об'єктами й суб'єктами діяльності DOTD є відділи CA, PO i SF. У кожному відділі Центру є відділення по роботі з персоналом, відділення теорії бойових дій і відділення розвитку навчання. Основні завдання відділів: розробка доктрин за своїми напрямами підготовки для довідників та керівництв 3 бойового застосування, навчальних посібників для слухачів, відпрацювання планів навчальних місій, стратегій підготовки 3 використанням зброї, графічної продукції й навчальних відеофільмів; оцінка поточної доктрини й розробка нових доктринальних концепцій, заснованих на вимогах ймовірних місій і потребах сил.

Завданням Центру інтеграції досвіду армійських спеціальних операцій (ARSOCIC) є збір, аналіз, поширення відповідних спостережень, уявлень та уроків ССО, визначення й вивчення перспективних вимог до спецоперацій, розробка концепцій, військових ігор та експериментів, розвиток та інтеграція армійських доктрин $з$ об'єднаними й загальновійськовими 3 метою досягнення загальнонаціональних стратегічних цілей.

Відділ навчання, освіти та розвитку лідерів (TLDE) виконує такі основні функції: підтримка загальної професійної військової освіти ССО в рамках моделі постійного (протягом служби й в резерві) підвищення кваліфікації офіцерів, ворент-офіцерів та сержантів; впровадження освіти, яка орієнтована на дистрибутивне (дистанційне) навчання 3 використанням комп'ютерних інструкцій та віртуального набору інструментів місій; організація управління навчанням.

Центр кадрової політики та програм ARSOF підтримує функції життєвого циклу персоналу, забезпечує підрозділи стратегічними 
доктринами, рекомендаціями, навчальними продуктами та загальними програмами з управління персоналом.

Відділ медіа виробництва (MPD) перетворює складні концепції та доктрини в навчальні доктринальні продукти, що допомагають військовослужбовцям ССО виконувати свої завдання. Відділ має два взаємопов'язані відділення: редакційне та візуальної інформації, що розробляє графіку для посібників та пов'язаних з ними навчальних продуктів (U.S. Army Special Operations Center of Excellence Organizational Chart, 2020).

Школа спеціальних бойових дій готує і навчає бійців Сил спеціальних операцій армії (ARSOF) і фахівців Командування спеціальних операцій США (USASOC) - полків CA, PO і SF бути готовими до участі у спільних військових операціях, розробляє перспективні способи ведення бойових дій.

У Школі організовуються й проводяться постійні курси для солдатів, сержантів, ворент-офіцерів й офіцерів регулярної армії (Active Component - AC), військовослужбовців резерву (Reserve Component - RC), а також для слухачів Департаменту цивільного корпусу армії США (Department of the Army civilians), іноземних бійців спільних спецоперацій і студентів згідно 3 військовообмінними програмами. Широкого поширення набули заняття за програмами дистанційного навчання Academic Handbook FY 2016, 2016). Для усіх категорій слухачів впроваджено такі основні курси: Цивільних справ (Civil affairs courses), Психологічних операцій (Psychological operations courses), Сил спеціального призначення США (Special forces courses), Сил спеціальних операцій армії США (ARSOF courses), медичної підготовки (Medical courses), мовної підготовки CCO (SOF language courses), курси підвищення кваліфікації (Staff and faculty development division courses), а також курси підготовки сержантів й ворент-офіцерів.

Загалом SOCoE пропонує 41 унікальний курс, який дає солдатам необхідні навички, щоб вижити та досягти успіху на полі бою. За навчальними програмами щоденно навчаються приблизно 3100 студентів. Заняттями та польовими вправами керують понад 400 досвідчених військових інструкторів, кожен з яких проходив службу у тих же підрозділах і в таких самих умовах, що і їх курсанти. Реальний бойовий досвід не тільки покращує навчання на курсах: він сприяє товариству, побудованому на спільному почутті обов'язку та відданості. Щорічно третина 
інструкторів повертається назад до бойових частин, з яких вони прибули. В період, коли військовий персонал виконує бойові завдання, понад 200 цивільних інструкторів, співробітників та експертів підтримують навчальний процес, розвивають доктрини, збагачуючи курсантів унікальним набором компетенцій і вмінь (Academic Handbook FY 2020, 2020).

До складу школи спеціальних бойових дій імені Дж. Кеннеді входять наступні формування: 1-ша тренувальна повітрянодесантна група спеціальних бойових дій (1st Special Warfare Training Group (Airborne)), освітня повітрянодесантна група спеціальних бойових дій (Special Warfare Education Group (Airborne)), повітрянодесантна група медичної підготовки (Special Warfare Medical Group (Airborne)), інститут ворент-офіцерського складу, (Special Forces Warrant Officer Institute (Airborne)), Академія сержантського складу імені мастер-сержанта Девіда К. Тума (Noncommissioned Officer Academy) (Academic Handbook FY 2016, 2016).

1-ша тренувальна група спеціальних бойових дій (повітрянодесантна) безпосередньо здійснює підготовку військовослужбовців підрозділів спеціального призначення із загальних питань ведення спеціальних операцій. На базі групи військовослужбовці навчаються як індивідуальним, так і колективним діям, готуються фахівці по роботі з місцевим населенням у ході проведення різного виду спеціальних операцій в умовах сучасної оперативної обстановки. Ця група складається 3 шести навчальних батальйонів і одного батальйону забезпечення навчального процесу.

Освітня група спеціальних бойових дій (повітрянодесантна) займається підготовкою військовослужбовців підрозділів спеціального призначення по наступних основних питаннях: навчання іноземним мовам, культурології, адаптивному мисленню, біхевіоризму (теорії поведінки особистості) і командним навичкам. При цьому всі слухачі проходять навчання за різними методиками й програмами. Група складається з чотирьох відділень.

Група медичної підготовки спеціальних бойових дій (повітрянодесантна) орієнтована на всебічне навчання і професійну підготовку медичного персоналу USASOC всіх видів збройних сил. Група складається 3 двох відділень: медичного і вивчення проблем виживання у воді.

Інститут ворент-офіцерського складу (повітряно-десантний) дає професійну військову освіту помічникам командирів оперативних 
загонів спеціального призначення. За статусом ворент-офіцер займає проміжне положення між сержантами й молодшими офіцерами та виконують функції технічного спеціаліста. Після ii завершення призначеним кандидатам присвоюється звання ворентофіцера 1-го класу. На базі інституту організовано три курси підготовки ворент-офіцерського складу підрозділів спеціального призначення: тактико-технічний, удосконалення і штабний.

Академія сержантського складу імені мастер-сержанта Девіда К. Тума проводить основну професійну підготовку цього контингенту з військово-обліковими спеціальностями СMF 18,37 і 38 відповідно до стандартів сухопутних військ США, а також навчання $з$ питань організації розширеної взаємодії на полі бою i розуміння оперативних можливостей і обмежень підрозділів спеціального призначення. Академія є головним елементом навчального центру, на базі якої організовуються заходи, що забезпечують високу якість профвишколу й освіти всього сержантського складу підрозділів спеціального призначення. (Турыгин, 2018: 42).

Військовослужбовці, які служать в армії США або вже відслужили й виявили бажання проходити службу в спецпідрозділах США (USASOC): групи спеціального призначення - «зелені берети», 95-та бригада військово-цивільного адміністрування армії США, 4-та й 8-ма групи інформаційного забезпечення військових операцій армії США, а також в спецпідрозділах армії (ARSOF) об'єднаного Командування спеціальних операцій JSOC: 75-й полк рейнджерів, 1-й загін Сил спеціальних операцій «Дельта», 528-ма бригада підтримки, тощо (What's wrong with ARSOF?, 2018), проходять 3-тижневий етап оцінки та відбору кандидатів на навчання y SOCoE. Заяви на прийняття в підрозділи CCO можуть подавати тільки військовослужбовці, що вже мають досвід стрибків із парашутом. Протягом усього етапу їм заборонено будь-яке спілкування із зовнішнім світом. Це необхідно для того, щоб зпоміж кандидатів відібрати найбільш психологічно підготовлених і стійких. Далі проходить медична комісія, перевірка фізичної підготовки й знову комісія, що перевіряє фізичні якості кандидата, його стан після навантажень. За результатами виконання ряду тестів: плавання, біг, смуга перешкод, марш-кидки, орієнтування на місцевості - комісія вирішує, кого 3 кандидатів допустити до наступної фази цього етапу, на якій оцінюються 
психологічні якості бійців. 3 усіх кандидатів лише близько сорока відсотків успішно виконують всі нормативи, решта повертається назад у свої військові частини. Кандидати, які пройшли етап відбору, вивчатимуть програми кваліфікаційних курсів поглиблено протягом 5-6 місяців, при цьому кожен вивчає всі спеціальності незалежно від обраного напряму.

Під час першого етапу основного кваліфікаційного курсу (7 тижнів) слухачі ознайомлювалися з історією, принципами їх застосування, призначенням, завданнями, ключовими принципами, а також зі способами й формами дій. На другому етапі проводяться заняття за програмами лінгвістичних курсів, що присвячені вивченню іноземних мов (усього в Школі вивчають 14 мов) і країнознавства з урахуванням ймовірного регіону застосування. Залежно від складності мови курс займає до 25 тижнів. Основна увага приділяється усному мовленню, сприйняттю іноземної мови на слух і вивченню військової термінології. Після закінчення курсу курсанти направляються на стажування до групи за своєю мовною спеціалізацією. Третій етап (13 тижнів) спрямований на відпрацювання тактики дій у складі малих підрозділів. Четвертий етап (від 14 до 50 тижнів) - спеціалізація, протягом якої вивчається спеціальне озброєння, інженерносаперна справа, зв'язок, закріплюються медичні знання, вдосконалюються навички парашутної підготовки. П'ятий етап (чотири тижні) присвячений перевірці набутих знань 3 використання спеціальних способів бойових дій на практиці. Шостий етап (один тиждень) передбачає оцінку отриманих під час навчання знань. Один раз на рік бійці проходять збори за програмою курсів підвищення кваліфікації, де складають тести, що підтверджують їх профпридатність і вивчають нові зразки озброєння та перспективні доктрини застосування ССО (Слюсаренко, 2019: 171).

Збройні Сили України не стоять осторонь світових тенденцій розвитку Сил спеціальних операцій. Після анексії Криму з початком збройної агресії й в умовах гібридної війни розв'язаної Російською Федерацією на Сході України, постало питання прискорення розпочатого ще у 2007 році процесу формування CCO Збройних Сил України. Завдяки бойовому досвіду, набутому військово-політичним керівництвом та підрозділами спеціального призначення, з'явилась необхідність відокремлення Сил 
спеціальних операцій в окремий рід сил і започаткування ефективної фахової підготовки на рівні спецпідрозділів провідних країн. 16 червня 2016 року Верховна Рада затвердила створення Сил спеціальних операцій Збройних Сил України. На той час 14 травня 2016 року вже відбувся перший випуск 29 інструкторів навчально-тренувального центру Сил спеціальних операцій кваліфікаційного курсу в рамках програми «Об'єднаної багатонаціональної тренувальної групи - Україна» (Joint Multinational Training Group - Ukraine, JMTG-U), а 15 листопада 2016 року у м. Хмельницький відбувся випуск ще 35 інструкторів ССО. Багатонаціональна група складалась 3 фахівців США, Литви, Латвії та Естонії. Кваліфікаційний курс відповідно до програми підготовки тривав 6 місяців (Сили спеціальних операщуій Збройних Сил Украӥни поповнили 35 інструкторів, 2016). 6 грудня 2016 року був створений 142-й навчальний центр Сил спеціальних операцій Збройних Сил України у м. Бердичів Житомирської області. Навчальний процес фахівців в Центрі організовано за стандартами НАТО і відрізняється не лише високими вимогами щодо добору кандидатів на службу - відбір у ССО проходять лише $10 \%$ кандидатів, але й підготовкою особового складу. В нові спецпідрозділи потрапляють високомотивовані, стресостійкі та досвідчені військові. На відбірковому етапі курсу курсанти упродовж трьох тижнів живуть в наметах на полігоні без будьякого зв'язку із зовнішнім світом. Заборонені навіть СМС рідним. Пересуватись по табору дозволено лише перебіжками. Якщо хтось порушить це правило, його чекає покарання. Щоденні фізичні навантаження витримують не всі - чимало кандидатів здаються, інші не проходять психологічного відбору. На тих, хто успішно пройшов відбір, чекає навчання, під час якого кожен військовослужбовець повинен освоїти одну з п'яти спеціалізацій командира, інженера, фахівця з озброєння, медика або зв'язківця. Усі спеціалізації є взаємозамінними (Приєднатись. Сили спеціальних операцій ЗС Украӥни, 2016).

Підтвердженням прагнень щодо інноваційної підготовки вітчизняних фахівців-лідерів Сил спеціальних операцій є те, що в межах навчання «Flaming Sword 2019» спецпідрозділ Збройних Сил України вперше пройшов акредитацію та сертифікацію за стандартами SOF NATO та був визнаний боєготовим для участі в 
операціях Сил реагування НАТО (NATO Response Force) у 2020 році (Украӥнські ССО иче зробили, 2019).

Висновки. Проаналізувавши історичний досвід у формуванні кадрового потенціалу спецпідрозділів США, варто зауважити, що передумовами створення ССО й організації цілеспрямованої підготовки фахівців сухопутного компонента спецпідрозділів армії США в середині XX ст. та ЗСУ на початку XXI ст. стали прагнення до світового лідерства тоталітарних режимів, зокрема колишнього комуністичного СРСР і сучасного його послідовника Російської Федерації. 70-річний шлях творення Сил спеціального призначення й системи підготовки висококваліфікованих фахівців в період протистояння комуністично-терористичним та екстремістським організаціям дозволив збудувати модель військової школи майстерності, яка на сьогодні є динамічною структурою, що постійно розвивається відповідно до викликів сучасності. Удосконалюється структура закладу, зміст і спектр кваліфікаційних курсів, впроваджується дистрибутивна форма навчання. Навчальні програми армійських ССО інтегруються в систему підготовки підрозділів об'єднаних Сил.

Уважне вивчення й аналіз інновацій освіти, функцій структурних елементів Центру майстерності спеціальних операцій армії США, безсумнівно, може посприяти подальшому розвиткові системи підготовки вітчизняних фахівців, особливо в умовах переходу Збройних Сил України на ј-структури органів військового управління країн-членів НАТО. Фахова підготовка спецпідрозділів на рівні вишколу бійців Сил спеціальних операцій армії США дасть змогу підвищити потенціал військ і якість виконання завдань за призначенням в районі проведення Операції об'єднаних сил на Сході України, а в майбутньому - стати надійним висококваліфікованим партнером НАТО і залучатись до участі у проведенні спільних операцій Північноатлантичного альянсу.

Перспективою подальших розвідок у цьому дослідженні $\epsilon$ вивчення історичної динаміки впровадження кваліфікаційних курсів Центру майстерності спеціальних операцій, поглиблений аналіз змісту й обсягу, застосування їх в процесі навчання конкретних категорій слухачів, що дасть змогу використовувати досвід провідного закладу освіти Сил спеціальних операцій в підготовці фахівців Збройних Сил України. 


\section{Використані посилання}

Academic Handbook FY 2016. Special warfare. USAJFKSWCS course catalog (2016) [online] Available from https://www.soc.mil/SWCS/academichandbook.html [Accessed 10 January 2020].

Academic Handbook FY 2017. Special warfare. USAJFKSWCS course catalog (2017) [online] Available from https://www.soc.mil/SWCS/academichandbook.html [Accessed 10 January 2020].

Academic Handbook FY 2019. Special warfare. USAJFKSWCS course catalog (2019) [online] Available from https://www.soc.mil/SWCS/academichandbook.html [Accessed 10 January 2020].

Kennedy J. F. (1962) United States Military Academy Commencement Address [online] Available from https:/www.americanrhetoric.com/ speeches/ jfkwestpointcommencementspeech.htm [Accessed 10 January 2020]

USAJFKSWCS dedicates Kennedy-Yarborough statue (2012). Special Warfare. Vol. 25. ISSUE 2. p. 5.

U.S. Army Special Operations Center of Excellence Organizational Chart (2020) [online] Available from: https://www.soc.mil/SWCS/organization.html [Accessed 10 January 2020]

What's wrong with ARSOF? (2018) Small Wars Journal [online] Available from https://smallwarsjournal.com/jrnl/art/what\%E2\%80\%99s-wrong-with-arsof [Accessed 10 January 2020]

Вєдєнєєв Д.В., Биструхін Г.С., Семука А.І. (2010). Гострі кігті орла. Сили спеціальних операчій США: історія та сучасність. Монографія. Київ: К.І.С., 512 с.

Еволюиія структур інформаційно-психологічного протиборства сил спецоперацій армї (2019) [online] Доступно: http://opk.com.ua/ еволюція-структурінформаційно-псих [Дата звернення 16 січня 2020].

За два роки очікуються реформи військової освіти (2019) [online] Доступно https://www.kmu.gov.ua/news/za-dva-roki-ochikuyutsya-reformi-vijskovoyi-osvitiminoboroni [Дата звернення 9 січня 2020]

Історія створення Сил спеціальних операцій 3С України (2020) [online] Доступно https://ukrsof.com/faq/history/ [Дата звернення 12 лютого 2020].

Коммандос: Формирование, подготовка, выдающиеся операщии спецฺподразделений (1999) [online] Доступно: http://militera.lib.ru/research/ miller/ index.html [Дата звернення 29 січня 2020].

Мартьянов О. (2010) Центр и Школа специальных способов ведения войны Сухопутных войск США. Зарубежное военное обозрение, № 11. С. 35-39.

Метров О. (2014) Комплектование и подготовка личного состава Сил специальных операций ВС США. Зарубежное военное обозрение, № 11. С. 40-49.

Національну академію сухопутних військ відвідали експерти НАТО. (2019) [online] Доступно http://www.asv.gov.ua/?q=news/2019/05/13/nacionalnu-akademiyusuhoputnyh- viysk-vidvidaly-eksperty-nato [Дата звернення 9 січня 2020].

Приєднатись. Сили спещіальних операцій ЗС України (2016) [online] Доступно http://sof.mil.gov.ua/join [Дата звернення 16 лютого 2020].

Сили спеціальних операщій Збройних Сил України поповнили 35 інструкторів. (2016) [online] Доступно http://www.mil. gov.ua/news/ 2016/11/15/ sili-speczialnihoperaczij-zbrojnih-sil-ukraini-popovnili-35-instruktoriv/ [Дата звернення 16 лютого 2020] 
Слюсаренко А.В. (2019). Світовий досвід розбудови та застосування сухопутного компонента Сил спеціальних операцій (друга половина XX початок XXI cm.). Львів: НАСВ, 420 с.

Турыгин А. (2018). Учебный центр сил специальных операций сухопутных войск США. Зарубежное военное обозрение, № 4. С. 39-47.

Украӥнські ССО цее зробили (2019) [online] Доступно: <http://www. mil. gov. ua/news/2019/07/27/ukrainski-sso-cze-zrobili!/> [Дата звернення 29 січня 2020].

\section{Referencces}

Academic Handbook FY 2016. Special warfare. USAJFKSWCS course catalog (2016) [online] Available from https://www.soc.mil/SWCS/academichandbook.html [Accessed 10 January 2020].

Academic Handbook FY 2017. Special warfare. USAJFKSWCS course catalog. (2017) [online] Available from https://www.soc.mil/SWCS/academichandbook.html [Accessed 10 January 2020].

Academic Handbook FY 2019. Special warfare. USAJFKSWCS course catalog. (2019) [online] Available from https://www.soc.mil/SWCS/academichandbook.html [Accessed 10 January 2020].

Evolution of structures of information and psychological confrontation of special operations forces of the army (2019) [online] Available from: <http://opk.com.ua/ evolution-structures-information-psycho> [Accessed 16 January 2020] (ukr).

History of the Special Operations Forces of the Armed Forces of Ukraine (2020) [online] Available from <https://ukrsof.com/faq/history/> [Accessed 12 February 2020] (ukr).

Join. Special Forces of the Armed Forces of Ukraine (2020) [online] Available from <http://sof.mil.gov.ua/join> [Accessed 16 February 2020] (ukr).

Kennedy J. F. (1962) United States Military Academy Commencement Address [online] Available from https://www.americanrhetoric. com/speeches/ jfkwestpointcommencementspeech.htm [Accessed 10 January 2020]

Martyanov O. (2010) Center and School of Special Ways to Fight the US Army. Foreign Military Survey № 11. pp. 35-39 (rus).

Metrov O. (2014) Acquisition and preparation of the US Armed Forces Special Operations Forces. Foreign Military Survey № 11. pp. 40-49. (rus).

Military education reforms are expected in two years (2019) [online] Available from: <https://www.kmu.gov.ua/news/za-dva-roki-ochikuyutsya-reformi-vijskovoyiosviti-minoboroni> [Accessed 9 January 2020] (ukr).

Miller D. Commandos. Formation, preparation, outstanding operations of special forces. (1999) [Online] Available from <http://militera. ib.ru/research/ miller/ index. html $>$ [Accessed 29 January 2020] (rus).

Slyusarenko A. World experience of development and application of the ground component of the Special Operations Forces (second half of XX - beginning of XXI centuries). Lviv, Hetman Petro Sahaidachnyi National Army Academy, 2019. 420 p. (ukr).

The National Army Academy was visited by NATO experts (2019) [online] Available from <http://www.asv.gov.ua/?q=news/2019/05/13/nationalnu-akademiyusuhoputnyh-viysk-vidvidaly-eksperty-nato> [Accessed 9 January 2020] (ukr). 
The Special Operations Forces of the Armed Forces of Ukraine enrolled 35 instructors (2016) [online] Available at: <http:// www.mil.gov.ua/news/ 2016/11/15/ silispeczialnih-operaczij-numbered-sil-ukraini-filled-35-instructoriv/> [Accessed 16 February 2020] (ukr).

Turygin A. (2018) US Army Special Operations Training Center Training Force. Foreign Military Survey. No. 4. C. 39-47 (rus).

U.S. Army Special Operations Center of Excellence Organizational Chart. (2020) [online] Available from: https://www.soc.mil/SWCS/organization.html [Accessed 10 January 2020]

Ukrainian SOF did it! (2019) [online] Available at: <http://www.mil. gov. ua/ news/ 2019/07/27/english-sso-cze-zrobili!/> [Accessed 29 January 2020] (ukr).

USAJFKSWCS dedicates Kennedy-Yarborough statue (2012). Special Warfare. Vol. 25. ISSUE 2. p. 5.

What's wrong with ARSOF? (2018) Small Wars Journal [online] Available from https://smallwarsjournal.com/jrnl/art/what\%E2\%80\%99s-wrong-with-arsof [Accessed 10 January 2020]

\section{Sira 0.}

\section{U.S. ARMY SPECIAL OPERATIONS CENTER OF EXCELLENCE: HISTORICAL EXPERIENCE IN THE FORMATION SPECIAL FORCES PERSONNEL POTENTIAL}

The article briefly describes the history of creation, development and operation of the U.S. Army's Special Operations Center of Excellence (SOCoE).

Important scientific and practical experience, theoretical foundations of the organization of the educational process $\mathrm{SOCoE}$ require comprehensive study, analysis and implementation in the domestic system of training specialists of special units, which is especially relevant in the conditions of war unleashed by the Russian Federation in the East of Ukraine. Theoretical and practical interest is the very functioning of such structures in the armies of foreign countries, their features, differences and common features with the Ukrainian system of training.

The study analyzed the concept of formation of personnel potential of special units and the structure of the Center. It is noted that the educational institution is not only a school of training experienced specialists of special units, but also a modern analytical center, a dynamic innovative structure, developing and improving in accordance with the challenges of the military and political situation today. The role of SOCoE as a mechanism that allows creating prerequisites for the successful resolution of common tasks entrusted to the units of the Special Operations Forces of the United States federal agencies and security agencies of foreign countries and Ukraine has been highlighted.

Professional training of special units at the level of training of fighters of the U.S. Army Special Operations Forces will improve the capacity of troops and the quality of performance of tasks for their intended purpose in the area of operation of the joint forces in the East of Ukraine, and in the future - to become a reliable highly qualified partner of NATO and be involved in joint operations of the North Atlantic Alliance.

Keywords: U.S. Special Operations Forces, military schools, U.S. Army Special Operations Center of Excellence, SOCoE, John F. Kennedy Special Operations Center and School, USAJFKSWCS, U.S. Special Operations Command, USASOC. 